УДК 782.1+78.071.2

DOI https://doi.org/10.31723/2524-0447-2021-32-2-12

\author{
Чень Сяо \\ ORCID: 0000-0001-9589-2512
}

здобувач кафедри історії музики та музичної етнографії

Одеської національної музичної академії імені А. В. Нежданової thensyao21@ukr.net

\title{
ПОНЯТТЯ КЛАСИЧНОГО В ОПЕРНІЙ ТВОРЧОСТІ ТА ЯВИЩЕ СУЧАСНОЇ ОПЕРНОЇ КЛАСИКИ
}

Мета дослідження - визначити способи категоризації класичного в музиці, що є найбільш відповідними як до історичного та ціннісно-смислового походження, конститутивних культурних ознак цього явища, так $і$ до типологічних показників оперної творчості - в їі інституціональній художньо-функціональній цілісності та музично-мовній специфіці. Методологія роботи зумовлюється поєднанням культурологічного, естетичного, аксіологічного та семантичного підходів, передбачає включення соціокомунікативного ракурсу оцінки художніх явищ та розширення дослідного поля оперознавства у бік сучасних оперних феноменів як наслідування класичним артефактам. Наукова новизна иієї статті полягає у доведенні значущості явища класичного в музиці як для музикознавчого дискурсу, так і для сучасної композиторської творчості. Доводиться, що нова актуальність класичного зумовлюється множинністю буття класичних музичних взірців у сучасному соціумі, у семантичній мережі сучасної культури. Це стає одним з важливих чинників оновлення уваги до класичних засад провідних музичних жканрів, зокрема опери, у творчості сучасних композиторів. Розкривається значення класичної музики - класичного типу музичного мовлення - як головної парадигми на сучасному етапі розвитку професійної академічної музичної традиції, зокрема оперної. Висновки засвідчують, що категоризація класичного в музииі спирається на усвідомлення історичного та ціннісно-смислового значення класичної музики, передбачає конкретизацію поняття про класичне стосовно саме музичного мистецького досвіду, виявляє суттєві дискусійні моменти в обговоренні явища класичної музики - музичної класики; виявляється надзвичайна важлливість $i$ широта класичного типу музичного мовлення, відповідно, потреба у збереженні класичного типу музичного мислення, що, зокрема, зумовлюе оперний метод сучасної композиторки К. Сааріахо.

Ключові слова: класична музика, музична класика, класичне музичне мовлення, оперна творчість, полісемантичність явища класичного.

(C) Чень Сяо, 2021 
Chen Xiao, Applicant at the Department of Music History and Musical Ethnography of the Odessa National A. V. Nezhdanova Academy of Music

The concept of classic in opera creativity and the phenomenon of modern opera classics

The purpose of the study is to determine the ways of categorizing the classical in music, which are most appropriate to the historical and value-semantic origin, constitutive cultural features of this phenomenon, and to typological indicators of opera - in its institutional artistic and functional integrity and musical-linguistic specificity. The methodology of work is determined by a combination of culturological, aesthetic, axiological and semantic approaches, involves the inclusion of socio-communicative perspective of assessment of artistic phenomena and expanding the research field of opera in the direction of modern opera phenomena as imitation of classical artifacts. The scientific novelty of this article is to prove the significance of the classical phenomenon in music - both for musicological discourse and for modern composition. It is proved that the new relevance of the classical is due to the multiplicity of existence of classical musical patterns in modern society, in the semantic network of modern culture. This is becoming one of the important factors in renewing attention to the classical principles of leading musical genres, including opera, in the works of contemporary composers. The significance of classical music - the classical type of musical speech - as the main paradigm at the present stage of development of the professional academic musical tradition, in particular opera, is revealed. The conclusions show that the categorization of the classical in music is based on awareness of the historical and value-semantic significance of classical music, specifies the concept of the classical in relation to the musical artistic experience, reveals significant points of discussion in discussing the phenomenon of classical music - classical music. The importance and breadth of the classical type of musical speech is extremely important, respectively, the need to preserve the classical type of musical thinking, which, in particular, determines the opera method of the modern composer K. Saariaho.

Key words: classical music, musical classic, classical musical speech, opera, polysemantic nature of the classical phenomenon.

Актуальність теми статті зумовлюється двома обставинами.

Першою є те, що поняття класичного, зокрема класичного в музиці, нині набуває нової значущості на багатьох рівнях естетичних та мистецтвознавчих досліджень, також приймаючи і певний психологічний резонанс, тобто переростає у загальногуманітарну категорію. Водночас, незважаючи на велику за обсягом літературу, присвячену явищу класичного, важко знайти задовільне спільне загальнозначуще поняття про класичне, особливо враховуючи його генетичну подвійність, а саме взаємодію історичних та теоретичних передумов у процесі його категоризації (див.: $[1 ; 3 ; 4 ; 6 ; 9 ; 11])$. 
Інша обставина виростає з намагання виявити парадигматичні риси оперної творчості як важливого суспільного феномена, тобто значення опери як осередку етичних та естетичних культурних нормативів, мистецьких канонів, котрі завжди організують оперну творчість, втілюються в оперно-мовних властивостях. Тобто актуальною постає потреба з'ясувати класичні риси оперного жанру і як історично сформовані, i як семантично задані, запрограмовані структурою та функціями саме такого жанру (див.: $[2 ; 5 ; 7 ; 8 ; 10 ; 12]$ ).

Зазначимо, що обидва аспекти актуальності вивчення класичного є відкритими, тобто такими, що не мають сталої системи оцінних підходів, а їх взаємозалежність підсилює складність проблеми. Водночас саме те, що для сучасного музиканта, також пересічного реципієнта, категорія взірцевості, як визнаності та ідеальності одночасно, як синонім досконалості, $є$ напрочуд важливою, проблема ця потребує вивчення й вирішення.

Передусім, звернемо увагу на те, що у визначеннях класичного в музиці - і як класичної музики також - поєднуються узагальнюючі естетичні та специфічні аналітичні музикознавчі підходи. Так, найчастіше вважається, що класична музика - це сфера музичних творів, які увійшли до так званого пантеону музичного мистецтва, отже, витримали випробування часом, можуть вважатися загальноприйнятими людською культурою. Разом із тим визнається, що до класичної музики найчастіше відносять музику професійної академічної традиції, від бароко до сучасності, з визначеними умовами музичної творчості та уявленнями про особу творця музики, iii функціональні здатності.

Недарма неодмінними є вказівки на зв'язок класичної музики з принципами мистецтва класицизму у його стильовій цілісності. Отже, загальною рисою у розумінні класичного типу музичної творчості є сприйняття його як серйозної діяльності, котра вимагає підготовки, вдумливого сприйняття, відрізняючись від інших різновидів музики як «легкої», розважальної. Однак нині існує власна класика і в галузі останньої, а межі академічного та позаакадемічного й неакадемічного взагалі за походженням мистецтва легко зсуваються й навіть не завжди можуть бути визначеними.

Важливою рисою класичного мистецтва, у тому числі й музичного, особливо за часів уже повної автономії художнього 
досвіду, тобто його відокремлення в особливу систему діяльнісних технологічних форм, постає антропоцентричність, причому з особливою цікавістю до побудови внутрішнього світу людини, тобто іiі психології, раціонально-логічних потреб та почуттєвих мотивацій; антропоцентризм Нового та Новітнього часів, що веде до певних мистецьких символічних відкриттів, відзначений тенденцією універсалізації - типологізації, що є одним з найбільш сталих показників класичного способу світосприйняття, світогляду. I, справді, саме до подібного відтворення людини як усуспільненої всезагальної істоти схильна класична музика. Але людське існування $є$ історично та персоналістично динамічним, і класичні моделі людини або художнє моделювання взірцевої особистості примушені змінюватися, набувати нових змістових наповнень та соціооцінних конфігурацій. Особливо рухливими є уявлення саме про те, чим безпосередньо займається музичне мистецтво: про дух і смисл, про істинне призначення людського життя та його загальний етос.

Тому метою цієї статті є визначення тих способів категоризації класичного в музиці, які є найбільш відповідними як до історичного та ціннісно-смислового походження, конститутивних культурних ознак цього явища, так і до типологічних показників оперної творчості, в іiі інституціональній художньо-функціональній цілісності та музично-мовній специфіці.

Основний зміст роботи. Творча діяльність людини, як відомо, може приймати різноманітні форми, однією з яких постає музичне мистецтво. Саме розуміння за посередництвом мистецтва так званого «внутрішнього світу» здатне привести людину до усвідомлення власних особистісних якостей та їх діапазону. Подібні прозріння завжди стосуються й відкриття метафізичних основ буття людини, підтверджуючи таким чином (або спростовуючи) істинність життєвих людських прагнень, намагань. Такий діалог людської свідомості iз загальносмисловими настановами людського буття можна назвати найбільш сталим та найбільш загальним, водночас фундаментально необхідним для формування людської психіки та психології, онтологічним та аксіологічним. Тому ідеї, що втілюються у музичному творі, пов'язані із закономірностями буття людського духу взагалі, але з їх проєкціями до певного історичного часу та етнічного простору, тобто з кожного разу новими орієнтаціями до динамічних потреб та інтересів 
людської свідомості. Однак саме з боку специфічної художньої системи музики, її мовного порядку та власного «Гносису» формуються константні явища, котрі зберігають свою основоположну значущість навіть за помітними змінами як історичного контексту, так і самого музичного тексту (див.: [1]). Йдеться про принципи музичної логіки - або про риси музичного логосу - котрі, по-перше, $\epsilon$ назавжди даними музиці як автономній художній формі й тому назавжди зберігаються в ній, по-друге, забезпечують здатність музики до створення прекрасного як, передусім, особливого тонусу переживання сприйнятої дійсності, тобто здатність до катартичного переображення такої дійсності.

Рухаючись у першому напрямі, а саме до тих засадничих рис, ознак, мовних потреб музики, що неодмінно зумовлені іiі класичними інтенціями (або ії пошуками класичного як взірцево-справжнього), варто звернутися до концепції В. Конен [6], згідно з якою головні закони класичної музики виражаються у встановленні принципів музичного письма, зокрема способів нотації; у відкритті сталих ладових закономірностей, зокрема мажоро-мінорної системи; у розвитку принципів гомофонно-гармонічного багатоголосся та узгодженні їх з попередніми поліфонічними канонами професійної музики високої духовної традиції; у виробленні жанрових нормативів відповідно до родових естетичних понять та визначенні масштабів музичної форми як розгортання музичного звучання у часопросторі за певними правилами та прийомами.

Саме останнє постає вирішальним у повороті європейської музичної культури доби класицизму, що усталила автономію музичного логосу, до образних завдань світоглядно-філософського рівня, до концептуалізації процесу музичного мовлення як такого; таким чином відкривається, як постійна й необхідна, функція музичного мистецтва пропонувати завершені образно-смислові моделі людського життя, здатні присовуватися до різних соціально-практичних ситуацій, що визначає особливу роль оперної жанрової форми.

Звідси до конститутивних рис класичної музики потрапляють дієвість і піднесеність переживання, що опосередковується музичним звучанням, складність та темпоральна розгорнутість музичної композиції, наявність власного набору формальних ознак, формування за автономними регламентованими принципами, майже повне ототожнення понять 
класичного мистецтва та академічного типу професіоналізму, причому останнє стосується не лише музичної творчості, а й інших видів мистецької діяльності.

Взаємодія, взаємозалежність класичного та академічного типів музичної творчості дотепер $є$ відкритим питанням, оскільки, з одного боку, обидва дійсно передбачають канонічність, довершеність, рівняння на взірець (взірці), універсальність етичних значень, обізнаність у галузі художньої умовності. Про спорідненість таких явищ свідчить і їх спільна історія, тобто єдиний історичний час становлення світського типу музичного професіоналізму та жанрових засад академічної традиції музичного мистецтва, також тісно пов'язаний зі становленням опери.

Але, з іншого боку, класичні музичні артефакти у період кінця минулого століття дуже наочно перетнули межу академічної та масової культури, стали одним з чинників популярної звичаєвої музики, не втрачаючи мовної специфіки, але, звичайно, зазнаючи тотальної реінновації у кожному випадку вживлення до іншого культурного контексту. Треба враховувати також і те, що явище переходу класичної музики до сфери масового споживання супроводжується розвитком тенденції нон-класичного у багатьох верствах культури, зокрема й в академічному мистецтві. Отже, й у власних протиріччях класичне та академічне, як інституціональні та конститутивні типи музичної творчості, виявляються спорідненими та пов'язаними спільною долею.

Низка сучасних гуманітарних досліджень (переважно у галузі культурологіі) пропонує розуміти класичну музику як гранично універсальну музична мову, яку можна використовувати у різноманітних соціальних та смислових контекстах (див., зокрема: [3; 11]). Стосовно ролі класичного та класичної музики формуються такі теоретичні уявлення та пропозиції.

По-перше, наголошується на розширенні функцій класичної музики в озвучуванні повсякденного середовища, що зумовлює наповнення різних життєвих просторів класичними музичними образами, але вже з іншим, локалізованим знаковим (емблематичним) ефектом. Таким чином, класична музика виявляє здатність не тільки «одухотворити» цивілізаційний простір, але й надати засобам технічного прогресу нових семантичних функцій, зокрема допомогти подолати 
«порожній час» як час очікування, створити ситуацію гранично надособистої опосередкованої комунікації соціуму 3 окремим індивідом, здіймаючись над звичаєвими мовними настановами певного соціопсихологічного середовища тощо.

По-друге, саме класична музика часто супроводжує процес роботи, як фізичної, так і інтелектуально-розумової, своєю присутністю сприяючи гармонізації свідомості працюючої людини, також привносячи у досить одноманітні операційні дії відчуття емоційно-смислової змістовності, надаючи явищу повторності (будь-чого) додаткового творчого значення, таким чином вносячи естетичний елемент в ужиткову діяльність людини.

По-третє, класична музика, особливо в певних своїх артефактах, що набули якості узагальнюючих соціокультурних маніфестів, на кшталт фіналу Дев'ятої симфонії Л. Бетховена, виступає могутнім чинником психологічного об’єднання людей у дійсно гуманітарну спільноту, що має єдині цілі та ідеали буття, оскільки завжди залишається «актуально-прекрасним» (Г. Гадамер) та носієм етичного позитиву. Тому, наприклад, озвучування класичною музикою офіційних заходів не тільки впорядковує часову організацію події, але й допомагає створити піднесену атмосферу, котра не є для більшості сучасних людей звичною, буденною, у тому числі вносячи елементи соціального перформансу, учасники якого повинні увійти у певні соціокомунікативні образи, тобто зіграти роль самих себе, але в нових обставинах та зі зміненими міжособистісними стосунками, ушляхетненими та більш значущими.

По-четверте, не можна не згадати роль класичної музики у сфері персональних технічних комунікацій, у звуковому оформленні телемережі та Інтернету, сигналів мобільних телефонів. Навіть виникає враження, що у випадках комунікацій за допомогою фрагментів класичних музичних творів сучасні користувачі електронної техніки стають своєрідними співавторами класичного твору, повністю змінюючи його інформаційне призначення, надаючи йому нової утилітарності, тобто й нового прагматизму. В усякому разі залишається незаперечним фактом, що класичні мелодії, серед яких важливим компонентом постають оперні мелодії, здатні входити до мовного середовища повсякденного спілкування, з одного боку, надаючи міжособистісному діалогу більш високого культурного статусу, з іншого - додаючи хрестоматійно відомому музичному 
матеріалу нового соціального сенсу, таким чином поглиблюючи його семантичні (художньо-мовленнєві) здатності.

По-п'яте, варто розрізняти зміст понять «класична музика» та «музичнакласика», оскільки саме останнє, на наш погляд, $є$ відкритим у жанровому сенсі, рівною мірою стосується як академічної традиції, так і масової музики, джазової культури, естрадного мистецтва тощо, тобто орієнтується на взірцеве та вибране, найбільш вживане в будь-якій сфері існування музичної творчості. Хоча й у цьому напрямі також ще не має достатньої теоретичної одностайності, оскільки існують внутрішні процеси художньо-змістової міграції у самій музиці, через що виникають перехідні форми творчості, що не належать остаточно до жодної з відомих сфер музики; також і розуміння поняття «мистецтво» набуває суттєвих змін, доповнюючись поняттями арт-дизайну, артифікації життя (побуту), медіа-арту, деякими іншими.

Загалом, в основі явища й поняття класичної музики - як і класичного в музиці - завжди залишаються незмінними три головні принципи, що відповідають трьом провідним функціям музичного діяння як художнього - формотворчо-композиційній когнітивній; інтонаційно-звуковій сугестивній; пізнавально-змістовій етичній: «зробленість» форми, що забезпечує якість гармонії; вибірковість інтонаційно-мотивного музичного матеріалу, що дозволяє дотримуватися ідеалу краси; установка на смисли, що породжені власним творчим досвідом музики як морально-естетичного феномена, іманентна змістовність, яка сприяє відчуттю досягнення істини, тобто здійснення певного ідеального уявлення про людину та доцільність ії життя.

Тому можна повністю погодитися 3 тим, що в основі музичної естетики класичного лежать основні ціннісні критеpiї істини, добра, краси, гармонії та смислу, а категорія класичного в музиці позначає якість художнього твору як інтеграцію етичного й естетичного, тобто як калокагатійне явище. Звідси й перевага в розумінні феномена музично-класичного саме аксіологічного підходу, що переростає у семантичний на рівні музичного тексту, матеріалу конкретних музичних композицій; такий підхід дозволяє також засвідчувати ефекти множинності і музичного смислу, і значення класичного в музиці, тобто вказувати на полісемантичність явища класичного музичного образу. 
Саме завдяки такій семантичній множинності класична музична традиція, як єдиний історичний феномен, постає предметом композиторської уяви в оперній творчості К. Сааpiaxo.

Як дозволяють судити про це результати сучасних наукових досліджень, зокрема праця Н. Саамішвілі [10], у своїх операх Сааріахо звертається до різноманітних шарів світової культури та використовує численні алюзії, прагнучи до створення складного, «багатошарового» оперного тексту, здатного сполучати часові виміри минулого, сьогодення й майбутнього, а тому в такій жанровій формі більш відчутний діалог композиторки з класичною традицією європейського музичного мистецтва. Зокрема, композиція опери «Любов здалеку», заснованої на легенді про знатного трубадура, котрий відправився в далеке плавання до прекрасної Дами, яка виспівується ним у піснях, але на цьому шляху пошуку ідеалу захворів та врешті-решт помер на руках у бажаної коханої, відтворює вагнерівську ідею Liebestod, ідею злиття любові та смерті, тому відсилає до «Тристана та Ізольди» Р. Вагнера, але також і до «Пелеасу й Мелізанди» К. Дебюссі.

У процесі аналізу тексту цієї опери дослідниці вдалося виявити використання класичних оперних образних моделей як на рівні загальної композиції і способів розгортання сюжету, так і у царині музичної драматургії. Зокрема, доводиться, що музична драматургія опери організується повторюванням мотивних, ладо-гармонійних, тембрових елементів оперних мелодій, що приймають значення лейтхарактеристик, водночас мають спільне інтонаційне походження з теми далекої любові, яку можна сприймати як монотему всього твору.

Не менш сталим, таким, що може називатися класичним для оперної форми, є прийом зіставлення двох образних світів: трубадура Жофре (баритон) та прекрасної Дами Клеманс (сопрано); причому комплекс засобів, зв'язаний зі сферою Жофре, з одного боку, відсилає до середньовічних музичних феноменів (діатоніка з вкрапленнями модальних зворотів, «чисті» квінти арф і струнних у супроводі»), а 3 іншого вказує на його романтичну палкість, пасіонарність (вокальна партія втрачає кантиленність, у ній підсилюється декламаційність, діатоніку зміняє хроматика тощо).

3 образом Клеманс до опери входить східний колорит (з відтінками імпресіоністичних гармоній, найбільше в 
інструментальному звучанні), але також і експресіоністська вокальна техніка (широкий спектр засобів вокалізації передбачає яскраву виразну декламацію 3 охопленням широкого діапазону, складними інтонаційними стрибками й навіть переходом на говір, що нагадує прийоми Schprechstimme) взагалі притаманна К. Сааріахо.

Таким чином, можна стверджувати, що видатна фінська композиторка намагається узагальнити музичну поетику європейської опери як взірцеву, використовуючи іiі основні елементи на всіх рівнях оперної композиції, головне - надаючи оперній жанровій формі оновленого значення сучасної музичної класики.

У цьому творі Сааріахо виникає розгорнутий діалог 3 історичним часом європейської опери як єдиним художнім феноменом, симультанність сприйняття й відтворення якого можна передати саме музично-інтонаційним шляхом. Причому зберігаються всі головні критерії підходу до класичного в музиці: ідеалом на сюжетному та музичному шляху героїв опери залишаються краса, гармонія, істинність почуття. Прагнення цього ідеалу виражене як настільки могутнє, що примушує йти на граничні жертви, включаючи розставання 3 власним життям, а це дозволяе знаходити в оперній творчості К. Сааріахо приклад реінновації класичної оперної теми фатуму.

Наукова новизна цієї статті полягає у доведенні значущості явища класичного в музиці як для музикознавчого дискурсу, так і для сучасної композиторської творчості. Доводиться, що нова актуальність класичного зумовлюється множинністю буття класичних музичних взірців у сучасному соціумі, у семантичній мережі сучасної культури. Це стає одним з важливих чинників оновлення уваги до класичних засад провідних музичних жанрів, зокрема опери, у творчості сучасних композиторів. Розкривається значення класичної музики класичного типу музичного мовлення - як головної парадигми на сучасному етапі розвитку професійної академічної музичної традиції, зокрема оперної.

Висновки зі змісту цієї статті засвідчують, що категоризація класичного в музиці спирається на усвідомлення історичного та ціннісно-смислового значення класичної музики, передбачає конкретизацію поняття про класичне стосовно саме музичного мистецького досвіду, виявляє суттєві дискусійні 
моменти в обговоренні явища класичної музики - музичної класики. Водночас виявляється надзвичайна важливість і широта класичного типу музичного мовлення, відповідно, потреба у збереженні класичного типу музичного мислення, що, зокрема, зумовлює оперний метод сучасної композиторки К. Саaрiaxo.

\section{СПИСОК ЛИТЕРАТУРЫ}

1. Арановский М. Музыкальный текст. Структура и свойства. Москва : Композитор, 1998. 343 с.

2. Богатырев В. Оперное творчество певца-актёра: историкотеоретические и практические аспекты : дисс. ... доктора искусствоведения : 17.00.09 «Теория и история искусства». Санкт-Петербург, 2011. $335 \mathrm{c}$.

3. Журкова Д. Классическая музыка в современной массовой культуре России : автореф. ... канд. культурологии : 24.00 .01 «Теория и история культуры». Москва, 2012. 24 с.

4. Классика музыкальная. Музыкальная энциклопедия. / Гл. ред. Ю.В. Келдыш. Москва, 1974: Т. 2. С. 8-25.

5. Коляденко Н. Синестетичность музыкально-художественного сознания (на материале искусства XX века) : дисс. ... докт. искусствоведения : 17.00.02 «Музыкальное искусство». Новосибирск, 2006. $491 \mathrm{c}$.

6. Конен В. Третий пласт. Новые массовые жанры в музыке XX века. Москва, 1994. 160 с.

7. Кузнецов Н. Сценическое мастерство оперного артиста в контексте актерской школы Ф.И. Шаляпина : дисс. ... докт. искусствоведения : 17.00.02 «Музыкальное искусство». Москва, 2005. 380 с.

8. Лю Цзинь. Оперная культура современного Китая: проблема подготовки исполнительских кадров : дис. ... канд. пед. наук : 13.00 .02 «Теория и методика обучения и воспитания». Санкт-Петербург, 2010. $173 \mathrm{c}$.

9. Пинягина И. Роль классической музыки в формировании личности : автореф. ... канд. философ. наук : 09.00.11 «Социальная философия». Уфа, 2014. 22 с.

10. Саамишвили Н. Оперы Кайи Саариахо 2000-х гг.: художественные идеи, музыкальная драматургия, композиционная техника : автореф. ... канд. искусствоведения : 17.00.02 «Музыкальное искусство». Москва, 2021. 24 с.

11. Царева Г. Классическая музыка как константа культуры и многоплановая реальность : автореф. ... канд. культурологии : спец. : 24.00.01 «Теория и история культуры». Саранск, 2007. 21 с.

12. Чжан Кай. Современный оперный театр как художественное явление и категория музыковедческого дискурса : дисс. ... канд. искусств. : 17.00.03 «Музыкальное искусство». Одесса, 2017. 186 с. 


\section{REFERENCES}

1. Aranovsky, M. (1998). Musical text. Structure and properties. Moskva : Composer [in Russian].

2. Bogatyrev, V. (2011). Opera work of the singer-actor: historicaltheoretical and practical aspects. Doctor's thesis of Arts : 17.00.09 "Theory and history of Art”. St. Petersburg [in Russian].

3. Zhurkova, D. (2012). Classical music in modern mass culture of Russia: author. ... cand. cultural studies : 24.00.01 "Theory and history of culture". Moscow [in Russian].

4. Musical classics. (1974). Musical encyclopedia. / Ch. ed. Yu.V. Keldysh. Moscow. T. 2. P. 8-25.

5. Kolyadenko, N. (2006). Sinestety of the musical-artistic consciousness (on the material of the art of the XX century). Doctor's thesis of Arts : 17.00.02 "Musical art". Novosibirsk [in Russian].

6. Konen, V. (1994). The third layer. New mass genres in the music of the 20th century. Moscow [in Russian].

7. Kuznetsov, N. (2005). Stage performance of an opera artist in the context of the acting school of F.I. Shalyapin. Doctor's thesis of Arts : 17.00.02 "Musical art". Moskva [in Russian].

8. Liu, Jin. (2010). Opera culture of modern China: the problem of training executive staff. Candidate's thesis ped. sciences : 13.00.02 "Theory and methods of training and education”. St. Petersburg [in Russian].

9. Pinyagina, I. (2014). The role of classical music in the formation of personality : author. ... cand. philosopher. sciences : 09.00.11 "Social philosophy". Ufa [in Russian].

10. Saamishvili, N. 2021. Operas by Kayi Saariaho in the 2000s: artistic ideas, musical drama, compositional technique : author. ... cand. art history : 17.00.02 "Musical art". Moscow [in Russian].

11. Tsareva, G. (2007). Classical music as a constant of culture and multidimensional reality : author. ... cand. cultural studies : 24.00.01 "Theory and history of culture". Saransk [in Russian].

12. Zhang, Kai. (2017). The modern opera theater as an artistic phenomenon and a category of musicological discourse. Candidate's thesis of Arts : 17.00.03 "Musical art". Odessa [in Russian]. 